\title{
THE ROLE OF FAMILY TIES IN AGENCY CONTRACTS
}

\author{
LUIS R. GOMEZ-MEJIA \\ Arizona State University \\ MANUEL NUÑEZ-NICKEL \\ ISABEL GUTIERREZ \\ Carlos III University
}

\begin{abstract}
Drawing on data based on the entire population of Spanish newspapers over 27 years (1966-93), this study shows that firm performance and business risk are much stronger predictors of chief executive tenure when a firm's owners and its executive have family ties and that the organizational consequences of CEO dismissal are more favorable when the replaced CEO is a member of the family owning the firm. The study also demonstrates that executives operating under weakly relational (less ambiguous) contracts are held more accountable for firm performance and business risk outcomes, even under nonfamily contracting.
\end{abstract}

The present study examines a variant of the agency contract, one that involves family ties between principal and agent. We argue that in such family-related contracting, the exchange departs from purely economic motives and that family bonds between principal and agent have as a consequence forms of behavior different from economic rationality. Specifically, we hypothesize that family-related contracting decouples agent's employment from performance and business risk and that the termination of agents who enjoy family status has a salutary effect on firm survival. Empirical results comparing family and nonfamily contracting support these hypotheses. Furthermore, we found that executives operating under more strongly relational contracts tend to be held less accountable for observed results, even under nonfamily contracting. A relational contract is one that broadly states the terms and objectives of an agency relationship. Such contracts are ambiguous rather than explicit; the parties "do not agree on detailed plans of action but on goals and objectives" (Milgrom \& Roberts, 1992: 131).

The study makes five important contributions to the firm governance literature. First, prior research has not examined the differences between familyrelated and non-family-related contracting. Therefore, the present study advances theoretical under-

This research was funded by the Spanish Commission for Science and Technology (CICYT Project: SEC 960637). The authors would like to thank three anonymous reviewers, faculty at IESE in Barcelona, and participants in the Human Resource Workshop at the University of Cadiz for their helpful comments, which made this a much better article. standing of relational contracts, where emotional rather than rational criteria govern the terms of the exchange. Second, the study suggests that family contracting is more likely to increase agency costs as a result of executive entrenchment. Furthermore, the study suggests that when firms engaged in family contracting put safeguards in place to curb these agency costs, firm survival improves. In prior theoretical work on agency theory, scholars have generally assumed that the threat of "moral hazard" and the costs of safeguarding against it are lowest in closely held firms because personal involvement by owner-managers supposedly eliminates the agency problem resulting from the separation of ownership and control (Jensen \& Meckling, 1976). Third, the study examines how the nature of a position affects the strength of a relational contract and the implications this has for executive monitoring.

Fourth, in a broader sense this study makes a contribution to management theory and practice by addressing the family business research lacunae. Our own reading of this literature confirms the disconcerting conclusion that "the vast majority of business school research either ignores, or at best, glosses over the role of family in owning or managing business enterprises" (Litz, 1997: 55). This is indeed surprising, given that family-owned businesses account for 40 to 60 percent of the U.S. gross national product and employ upward of 80 percent of the workforce (Neubauer \& Lank, 1998); these figures are much higher in most other countries (Madura, Martin, \& Jessell, 1996).

Lastly, and related to the prior point, the sample used for this study is valuable for reasons beyond family-related considerations because its members 
are from outside the United States. Management research, particularly on corporate governance, has been conducted mainly in North America and, to a lesser extent, in England. Our study covered the entire population of 276 Spanish newspapers during the period 1966-93. Most of these firms are relatively small and are family-owned, thus representing the prototypical firm in most of the world, unlike the large, Fortune 1000 U.S. firms normally used in agency research.

\section{CONCEPTUAL BACKGROUND}

\section{Family Contracting, Nonfamily Contracting, and Employment Risk}

In traditional agency models, assumptions of self-interest dictate that performance be precisely specified at the time of negotiation and be subsequently judged exclusively against that criterion (Harris \& Raviv, 1978; Shavell, 1979). If an agent fails to perform according to a principal's ex ante expectations, the agent can be readily replaced, so monitoring can keep agent opportunism in check (Ross, 1973). However, given bounded rationality and information asymmetries, it may be impossible for a principal to specify performance criteria ex ante and to contract for the services of the best possible agent. For instance, "adverse selection" may result in an agent's misrepresenting his or her capabilities. The notion of a relational contract accommodates the fact that in a situation other than a spot transaction, the principal can use knowledge and information about the agent during the exchange to determine if the agent is acting in the principal's interest. The agent is less inclined to act opportunistically because her or his welfare depends on future favors provided by the principal. Thus, relational, or long-term, contracting alleviates moral hazard problems stemming from divergence between the interests of principal and agent. Moreover, the principal can never be worse off in a long-term contract than in a sequence of short-term contracts because he or she can always replicate them in the long-term relationship (Lambert, 1983). Therefore, because relational contracting takes into account the possible future benefits of long-term relationships, it conforms to rationality conditions in agency theory, subject to certain constraints, such as incomplete contracting and opportunities for ex post negotiation (Milgrom \& Roberts, 1992). It differs from traditional agency formulations in that relational contracting "is never completely discrete (i.e., anonymous, characterized by limited communication)" (Zaheer \& Venkatraman, 1995: 374) but evolves over time as additional information be- comes available and the parties learn to have faith in each other (Kay, 1992). From this perspective, trust is valued because it is instrumental; that is, it makes the agency contract more efficient or optimal (Portales, Ricart, \& Rosanas, 1998).

In a family contracting situation, a relational contract between a firm owned by a family and an agent (a family member) involves a common bond and a set of mutual expectations that are more likely to be based on emotions and sentiments than a nonfamily relational contract. Therefore, family bonds engender agency contracts that are prone to depart from economic rationality. The literature on family business is full of anecdotal evidence showing that family connections have many nonrational consequences. These include inability to transcend parent-child dynamics (Handler \& Kram, 1988), sibling rivalry (Fahquar, 1989), or generational envy (Applegate, 1994); allowing "unconditional love and concern to conflict with business values of profitability and efficiency" (Dyer, 1988: 224); power based on ascribed rather than achieved status (Dyer, 1994); difficulty in dealing objectively with a family member's performance and qualifications (Crane, 1985); "inability to work rationally together toward an optimal resolution [which] needs an objective understanding of one another's positions, common interests, and respective differences" (Kaye, 1991: 6); and a lack of rational systems based on merit (Kanter, 1989).

Some authors have referred to family-owned businesses as "high trust" organizations (e.g., Jones, 1983) because they are governed by underlying informal agreements based on affect rather than on utilitarian logic or contractual obligations. This type of trust is very different from the "calculative trust" that undergirds much of the relational contract literature. It would be analogous to the concepts of "affective" (McAllister, 1995) or "relational" (Bigley \& Pearce, 1998) trust in the organizational behavior literature, whereby "emotion enters into the relationship between the parties... leading to the formation of attachments .... and entails a greater level of faith in the intentions of the other party" (Rosseau, Sitkin, Burt, \& Camerer, 1998: 394).

Under family contracting, both parties may attach value to the relationship that goes beyond the economic value created by transaction, and the perceived contributions of the agent may derive from kinship and often direct blood ties between agent and principal. Interaction between the two may go beyond that between a board of directors and a CEO, limited as it is to formal exchanges and reporting requirements reinforced by the existence of 
deterrents. Instead, the principal in a family-owned firm may be emotionally attached to the agent and thus may hold positive beliefs regarding this person's behavior or motives (Holmes, 1991).

Traditionally, agency models are concerned with the separation of ownership and control in diversified corporations, which gives rise to agency problems as executives may take advantage of their privileged positions vis-à-vis atomistic shareholders. A large number of studies have documented the presence of agency costs and the benefits of formal safeguards against them (such as closer monitoring of executives and performance incentives) in so-called management-controlled firms. These are generally defined as firms in which no single shareholder owns at least 5 percent of the stock. (For an extensive review of this literature, see Tosi et al. [1999]). Are there agency costs when an executive is part of the extended family that owns a business? Jensen and Meckling (1976) assumed that the blurring of the boundary between principal and agent in this type of family contracting would make moral hazard largely inconsequential. Yet the literature on family business is replete with examples of how agency problems may still arise under family contracting because the interests of the executive are not necessarily the same as those of the shareholders-the extended family. These agency costs under family contracting are compounded by the fact, noted earlier, that affective ties between the parties reduce the presence of formal safeguards designed to mitigate threats to firm performance. In other words, emotional aspects of the relationship may neutralize mechanisms to reduce agency costs, a situation that is less likely to occur under nonfamily contracting.

Agency threats under family contracting come in a variety of forms. First, there is the potential for incongruity between the goals of the executive and the family; thus, the executive may pursue objectives that are not in the best interests of the business. Anecdotal evidence from Donnelly (1964), Levinson (1983), Benson (1991), Davis and Haverston (1998), and others documents many problems under family contracting that parallel those discussed in the mainstream (nonfamily) corporate governance literature. These include attention to short-term profits rather than long-term goals; reluctance to be innovative, a classic risk avoidance posture; pursuing pet projects that enhance the executive's self-image; and empire building through sales maximization at the expense of profits. As Peiser and Wooten noted, "The [family executive's] interests may move in directions away from the firm, and what is best for him may cease to be best for the firm [thus] goal congruency becomes a prob- lem between family members themselves" (1991: 432).

Other agency threats under family contracting were suggested in a recent survey of 3,860 U.S. family business owners conducted by the Arthur Andersen Center for Family Business (Schulze, Dino, Lubatkin, \& Buchholtz, 1999). These include adverse selection, occurring because "the labor market that serves family firms is less efficient for various reasons [and characterized by a] smaller pool of applicants of more uncertain quality and limited promotional opportunities" (Schulze et al., 1999: 7). Another one is hold up, occurring because family executives may be able "to impose their self-serving desires onto the key decisions of the firm by holding owners hostage... [agents] may hold a disproportionate amount of power, emanating not only from the skills they may have (or may not posses) but more importantly from their family status" (Schulze et al., 1999: 8). Adverse selection and hold up occurring at the top may have a cascading effect on lower levels in a family business. For instance, lower-level managers may resent the implicit immunity top-level executives gain from their family status rather than from demonstrated performance and their ability to sustain their privileged positions by successfully threatening hold up. "[These] comparisons can motivate non-family employees to shirk and misrepresent information about their actions" (Schulze et al., 1999: 10).

Lastly, some research in the corporate governance literature indicates that closely held firms may incur agency costs, because CEOs who are part-owners of a firm may use their equity positions to consume perks that reduce the residual claims of other shareholders. That is, these executives may get away with self-serving behaviors precisely because their equity positions allow them to exercise more influence (Morck, Shleifer, \& Vishny, 1988). In fact, in his classical work on ownership structure, McEachern (1975) found that agency problems are as evident under conditions of high shareholder dispersion (management control) as under conditions of high executive ownership (owner management). Agency problems are lowest when major identifiable external shareholders own significant portions of firms, which are thus what McEachern called "externally controlled," a finding that has been replicated in numerous other studies (see the review by Tosi et al. [1999]). Therefore, by logical extension, executives may still act opportunistically, even though they are members of the families that own the businesses that employ them. In other words, one cannot assume that the motivation, desires, and concerns of a family executive are identical to those of other family share- 
holders or that the family executive will try to do what is best for the firm rather than pursue a personal agenda. Thus, goal conflicts between principal and agent under family contracting may give rise to the threat of moral hazard.

\section{Family Contracting, Firm Performance, and Managerial Tenure}

An agency cost that has received much attention from corporate governance scholars is managerial entrenchment, which refers to executives' holding their jobs past the point where their stewardship is beneficial to owners (see reviews by Gomez-Mejia and Wiseman [1997] and Walsh and Seward [1990]). Agency theorists, particularly in the management field, have recognized that executives will try to neutralize internal control mechanisms to ensure self-preservation. Walsh and Seward (1990) detailed many agent entrenchment approaches executives may use, including hiding or obscuring negative attributes, hiring consultants to legitimize decisions, convincing the board to recognize the primacy of environmental determinism, manipulating or biasing information, and making themselves irreplaceable (nonsubstitutable) by embarking on business strategies that capitalize on their idiosyncratic skills and abilities.

Entrenchment research, almost all of which has been conducted in large diversified firms, has shown that such agency costs are associated with high ownership dispersion, because use of monitoring is low (Tosi et al., 1999). On the basis of our prior discussion, we would also expect to find higher executive entrenchment under family contracting because emotions may color perceptions of the competence of executives, reducing monitoring effectiveness. In other words, family status leads to biased judgments about the appropriateness of executive decisions. Thus, assessment of agent performance under family contracting may shift negative performance attributions from the agent to exogenous forces; such assessment implicitly insulates agents from disciplinary action by recognizing extenuating circumstances that may be responsible for poor outcomes and may even alter the definition of performance ex post in light of those circumstances. Therefore, an agent-principal family contract is likely to reduce an executive's employment risk since the agent is not held directly accountable or liable for observed performance outcomes. The first hypothesis follows from the preceding arguments:

Hypothesis 1. The relationship between executive tenure and a firm's performance will be weaker for executives with family ties to the firm's owners than for executives without such family ties.

\section{Business Risk, Family Contracting, and Managerial Tenure}

An issue related to differential performancetenure sensitivity as a function of family versus nonfamily contracting is the extent to which executives who have family bonds to firm owners are sheltered from business risk. Because most of the agency literature has dealt with governance issues in corporations whose owners' portfolios are diversified, business risk is generally viewed as positive from the point of view of shareholders' welfare. In fact, an economically rational principal with a diversified (risk-neutral) portfolio of stocks will actually prefer riskier actions than will managers (who can't diversify employment risk because of their dependence on a single employer). This may increase the likelihood of lower returns for a particular firm yet will also increase the total expected returns of all the companies that form part of the principal's portfolio (Coffee, 1988). In other words, the presence of business risk in a particular firm may be seen by diversified stockholders as an indicator that its executives are pursuing the highrisk, high-return strategy that shareholders prefer (Baysinger, Kosnik, \& Turk, 1991).

In the case of smaller, closely held family firms, however, shareholders personally incur greater risks as a consequence of executive actions; thus, they will prefer lower business risks than their counterparts in large diversified firms. When a principal's ownership position is closely tied to one firm and options are constrained by high asset specificity, the principal prefers less business risk, since business failure may imply the loss of all returns (Chatterjee, Lubatkin, \& Schulze, 1999; Wiseman \& Gomez-Mejia, 1998). In other words, if a principal's wealth largely depends on a single investment, one would expect that the principal would be risk averse and would rather see agents behave in a risk-averse manner with respect to that investment. In line with the above logic, owners should be more prone to risk averseness in closely held family firms with fewer slack resources because risk bearing for them is inherently higher than it is for diversified corporate investors. In this context, principals are likely to see lower business risk as a sign that executives are protecting the family's patrimony (Hollander, 1983; Miller \& Rice, 1967), providing employment and financial security for the family (Liebowitz, 1986), and buffering the family firm from environmental instability (Das 
\& Teng, 1998). Paradoxically, although principals should be more risk-averse in a family business context, executives under family contracting are less likely to be penalized for evidence of high business risk because they are protected by their family ties to owners. That is, family contracts reduce the sensitivity of managerial tenure to business risk. For executives of family-owned firms who are not members of the extended family, business risk is likely to be seen as an agency threat, and they are more prone to be disciplined accordingly. Thus:

Hypothesis 2. Higher business risk is less likely to lead to an executive's dismissal when the executive is a member of the extended family that owns a firm than when there are no family bonds between the executive and firm owners.

\section{The Moderating Role of Executive Level: CEOs versus Editors}

Hypotheses 1 and 2 argue that, under nonfamily contracting, principals are more likely to hold executives liable for their actions because affect plays a lesser role than in the case of family contracting. At the same time, we expected that those executives who operate under more strongly relational contracts, even if they have no family ties to principals, should experience greater decoupling of tenure and objective, measurable results. Thus, we predicted that in our population of newspapers, the tenure of CEOs would be less sensitive to observed outcomes than the tenure of the editors who directly report to the CEOs. The reason for this is that, although "[all] exchanges include some relational elements" (Zaheer \& Venkatraman, 1995: 374), a contract with a CEO will by necessity be more strongly relational than a contract with an editor. Tasks are less programmable for a CEO, the job is more ambiguous, the transactions are more uncertain, and the human and procedural skills required are broader and less specific than they are for an editor.

The presence of a more relational contract for a CEO than for an editor relaxes the need for clear performance criteria and increases the expectation that performance will be evaluated more subjectively and reflect interpretations concerning the changing conditions surrounding the contract. Furthermore, compared to the editor, the CEO is generally expected to have a more stable, longer-term relationship with the newspaper's owners and to have more direct, continuous contact with them. (It is notable that in our population of newspapers, the average tenure of the
CEOs was 25 percent longer than that of the editors.) In the case of CEOs, this expectation of long-term contact allows owners "to diversify away some of the uncertainty surrounding the agent's actions" (Lambert, 1983: 442). Thus, although greater controls are still in place under nonfamily contracting (as per Hypotheses 1 and 2 ), the information value of observed outcomes decreases as principals develop more familiarity with a CEO, giving them a better opportunity to distinguish between unfortunate exogenous circumstances and mismanagement when they evaluate the executive. These arguments lead to $\mathrm{Hy}-$ pothesis 3:

Hypothesis 3. The relationship between firm performance, business risk, and executive tenure will be lower for executives operating under strongly relational contracts than for executives operating under weakly relational contracts.

\section{Agent Dismissal and Organizational Consequences}

The discussion leading to Hypotheses 1 and 2 concerns the employment consequences for an agent of the magnitude and riskiness of firm performance outcomes that depend on whether their agency contracts are family or nonfamily contracts. The next hypothesis concerns the normative implications for owners when chief executive officers are removed from office, the "so what" question raised by Tosi, Katz, and Gomez-Mejia (1997). In the context of this study, the most fundamental consequence to owners of CEO removal is its effect on organizational survival. The mortality rate of small businesses is rather high, and it is especially high for newspapers (Sohn, Ogan, \& Polich, 1986).

The question of whether or not managerial succession enhances firm survival "continues to intrigue organizational scholars because the empirical findings are inconsistent" (Haveman, 1993: 864). Carroll (1984) found that the dismissal of newspapers' executives augmented the mortality rates of these firms. In a different industry, Singh, House, and Tucker (1986) found the opposite results, revealing that the survival rates of voluntary service organizations improved in response to CEO successions. More recently, using a sample of early 20th century small telephone companies in southeastern Iowa, Haveman (1993) corroborated Carroll's findings that succession precipitated organizational mortality. She concluded that "clearly, the limited and conflicting evidence researchers have to date suggests that the relationship between managerial succession and organizational mortality needs further investigation" (1993: 865). 
The agency theory argument is that senior managers will be dismissed when the board responsible for monitoring their behavior has decided that they are incompetent or lagging behind their counterparts in competing firms in skills and abilities. In other words, employment risk is an integral part of the internal monitoring mechanisms used to discipline managers when firm performance is in jeopardy (Walsh \& Seward, 1990). As James and Sorel argued in their discussion of managerial exit, "Dismissal is the ultimate sanction which conditions their [managers'] behavior" (1981: 16). Other things being equal, by dismissing top managers who are deemed to be ineffective and replacing them with successors who presumably have more talent, firms should remain viable for longer periods of time. As is argued below, given that a family contract is more resilient than a nonfamily contract and thus that the former promotes greater tenure than the latter (as per Hypothesis 1 and 2), one would expect to find that removal of a family-member executive from a family-owned firm has a more positive impact on firm survival than the removal of a nonfamily executive.

Donnelly (1964) examined the history of selected family firms that survived and failed. He concluded that although family membership may give a manager greater employment security, "[Successful] firms have ensured, through establishment of formal checks as well as informal traditions, that these claims will not dominate" (Donnelly, 1964: 96). Donnelly also noted that replacement of top executives who were family members strengthened overall company morale by showing that "the right to manage has to be earned by family members in the same manner as by nonrelated employees. A relative's name may get him to the door but the rest is up to him" (Donnelly, 1964: 97). The broader strategy literature suggests that lengthy executive tenure may be detrimental to firms owing to a variety of factors, including low willingness to explore new market opportunities (Finkelstein \& Hambrick, 1996), increased complacency (Finkelstein \& Hambrick, 1990), poor strategic choices resulting from rigid decision processes (Katz, 1982), "tunnel vision" (Hambrick \& Fukutomi, 1991), and an overly conservative posture associated with the aging of a CEO (Coffee, 1988). To the extent that family-based contracts reduce the disciplinary effects of observed firm performance (as per Hypothesis 1) and business risk (as per Hypothesis 2) on CEO tenure, one would expect that if agency predictions are correct, a family-owned firm that takes the more drastic step of replacing a CEO who is a member of the family should survive longer. In other words, executive entrenchment is more likely to occur under family contracting (as per Hypotheses 1 and 2), so that executive transitions should have a more positive impact on firm survival in this situation than in a nonfamily context. Thus:

Hypothesis 4. CEO terminations will have a more positive effect on organizational survival under family contracting than under nonfamily contracting.

\section{METHODS}

\section{Research Setting and Data}

The population of firms for the study was all the daily newspapers published in Spain during the period 1966-93. We created the database, consisting of 276 newspapers, by pulling information from three separate sources. The first source was the Registry of Newspapers (Registro de Empresas Periodisticas). A listing in this registry became legally mandated for all newspapers published in Spain on March 18, 1966. The registry contains extensive information on each publication, including the title, founders, owners, number of pages, location, and target audience. Our second source, the Media Guide of Spain (Guia General de Medios), contains detailed demographic data on each firm and its top two executives, including when it was founded, when it ceased operations (if applicable), and the exact date of the hiring and termination (if any) of each CEO and editor. The last source is an ongoing report produced by an independent newspaper association, the Oficina de Justificacion de la Difusion, which shows the total number of newspapers that are produced and sold by each firm (circulation).

There were several advantages to using this population. First, as noted in the introduction, these organizations differ substantially from the type of firms generally studied by agency scholars. First, these are simpler organizations (in terms of size, product diversification, ownership structure, and such) than the complex, corporate, United Statesbased entities that are normally examined in the governance literature. These characteristics, which more closely depict the firms that are typical around the world, are valuable in assessing the generalizability of agency theory predictions about the sensitivity of executive tenure to firm performance and the consequences of agent removal. Thus, a distinct advantage of the database used here is the opportunity that it provides to study principal-agent relations outside of the traditional corporate governance framework.

Second, the use of newspapers as a population to test the hypotheses controlled for many extraneous 
factors that may affect the relationships among firm performance, business risk, executive tenure, and organizational survival. All the firms were (1) in the same industry, (2) in the same country, (3) insulated from global market forces, since competition for inputs and outputs and demand/supply factors in the newspaper industry are largely local, (4) exposed to similar historical forces during a single time period, and (5) not subject to as much information asymmetry and complexity as other types of firms, such as high-technology firms (e.g., Hambrick, Black, \& Fredrickson, 1992) or large diversified corporations (e.g., Hoskisson, Hitt, \& Hill, 1993). Furthermore, the jobs of CEO and editor are very similar across newspapers, so we were implicitly controlling for interorganizational differences in work-related tasks, responsibilities, and position requirements.

Third, it was possible to identify the family connections of these top executives, enabling us to test the effect of relational principal-agent contracts. ${ }^{1}$ Lastly, performance data for the newspapers (volume of circulation, as described later) were readily available, very straightforward, difficult to manipulate, and directly comparable from one newspaper to another and from one executive to another. As noted below, the circulation data also allowed us to calculate an index of business risk for the period corresponding to the tenure of each executive.

\section{Measures}

Family status. The presence or absence of family ties between principal and agent was determined separately for each CEO and editor. In the case of the CEO, we compared the last name with the last name of a newspaper's owners. In the case of the editor, who reports to the CEO, we confirmed family status if both executives had the same last name. Spain legally requires use of the last names of both father and mother, a practice that makes it easier to trace family ties.

\footnotetext{
${ }^{1}$ Information about the precise distribution of ownership within each newspaper is not publicly available. However, it is safe to assume that families play a key ownership role in these newspapers. Family names associated with ownership of the largest newspapers include Luca de Tena (Diario ABC), Polanco (El Pais), Asension (El Periodico de Cataluna), and De Salas (Diario 16). Families are likely to be in even stronger ownership positions among smaller (mostly local and regional) newspapers. Furthermore, prior to 1994 (the first year after the period used for this study), external investment in the newspaper industry of Spain was negligible.
}

Relational agency contract. Per Hypothesis 3, the degree to which an agency contract is relational should be stronger for a CEO than for an editor. The CEO reports to a firm's board of directors and is responsible for all strategic and financial affairs of the business. On the other hand, the newspaper editor is a professional journalist responsible for routine procedural matters, technical issues, implementation of the strategies traced by the CEO and the board (for instance, compliance with ideological orientation), the content of the newspaper, and staff supervision. The editor is explicitly hired to perform a job for a fee. Our analyses of the sensitivity of executive tenure to performance and business risk were conducted separately for the CEOs and the editors.

Executive tenure. For each CEO and editor, we recorded how much time had transpired between the date of hiring and the date of termination (if the individual had been replaced) or 1993 (if the individual was still on the job). In the latter case, the information was treated as "censored" data (Cox \& Oakes, 1984).

Performance. Financial earnings data were not available for the population of firms used in the study, and very few of these firms were publicly traded. An excellent performance measure for newspapers is the volume of circulation, a number that is not subject to accounting manipulation and that can be meaningfully and unambiguously tracked both longitudinally (within newspapers) and cross-sectionally (across newspapers). Furthermore, volume of circulation is the single most important variable that determines the advertising orders received by a newspaper and how much it can charge for ads (Smith, 1980). In turn, advertising is the main source of revenues for newspapers (Sohn et al., 1986).

We calculated two performance indicators using volume of circulation as an input. Performance trend consisted of the percent change in the number of newspapers sold from the time the executive took office to the time the executive departed (or to the end of 1993, if the executive was still in office). This measure of the growth (or decline) in newspaper sales during the executive's tenure was calculated separately for each CEO and each editor. Performance changes consisted of the percent change in the average number of newspapers sold between the tenure of a particular executive and the preceding executive. This index was also calculated separately for each CEO and editor. We used these two performance indexes as independent variables, with the executive's tenure as the dependent variable, to test Hypothesis 1 . 
Business risk. Performance variance relative to performance level is one of the most widely used measures of business risk in the strategic management literature (Ruefli, Collins, \& Lacugna, 1999). Lack of access to the newspapers' financial data and the fact that these firms were not publicly traded meant that we had to rely on circulation figures for our business risk indicator. Accordingly, business risk during the tenure of each executive was measured as the ratio of the variance in the volume of newspapers sold (circulation) divided by a term consisting of the average circulation minus the minimum circulation squared. Other things being equal, the more the average circulation for a given period exceeds the minimum circulation, the term in the denominator increases, and business risk decreases accordingly. Conversely, other things being equal, as the variance in the volume of newspapers sold (the numerator) increases during a given period, business risk increases accordingly. This index is similar to the coefficient of variation, which is widely used to measure a firm's business risk (see the 1995 review by Shapira). Miller and Reuer wrote that "the coefficient of variation is, by construction, positively related to the variance [of performance outcomes over time] and negatively related to the mean of the distribution ... hence, implicit in this measure is the notion that, for any given level of variance in performance, firms with higher mean [performance outcomes] have lower risk" (1996: 672). The ratio was subjected to a logarithmic transformation since the distribution that best fitted the data was "lognormal." We calculated this ratio separately for the period corresponding to the tenure of each CEO and each editor and used it as an independent variable, with the executive's tenure as a dependent variable, to test Hypothesis 2.

CEO succession. Two sets of dummy variables were created to measure the effect of CEO succession on organizational survival (as per Hypothesis 4), one set for CEOs who had family ties to owners and one set for those who did not have such ties. We coded each dummy variable as 1 if a firm had a particular succession and as 0 otherwise. We examined up to four successions for nonfamily CEOs and up to two for family CEOs since these ranges encompass over 90 percent of the exits during the 1966-93 period.

Length of survival. A measure was created to capture how long the newspaper remained in circulation following each CEO succession event up to the next succession event (if any). If the newspaper went out of business after a particular CEO's departure, the chronological difference between the date of succession and the date the paper ceased to be published was used as the measure of survival length. If the newspaper remained in business after a CEO was replaced, survival length was measured as the chronological difference between the two succession events. This variable was used as a dependent variable in tests of Hypothesis 4.

Control variables. As noted earlier, the population of firms used here effectively controls for many factors, including time period, industry forces, and technology. In the survival analysis (discussed below), we also excluded newspapers $(n=39)$ that had ties with the state's single party (El Movimiento) during the dictatorship of Generalisimo Francisco Franco, since some of these may have disappeared for political reasons after Franco's death in 1975. Other variables in the database, such as ownership of the printing house and type of newspaper, were not theoretically relevant to the study and did not exhibit a significant correlation with any of the independent or dependent variables of interest. To prevent loss of power, we did not include these in the multivariate analysis.

In view of prior research, we controlled for three variables. Density (the number of newspapers operating in a given period) and density squared (divided by 100 ) for the same period are both proxies for the extent of competition during a particular time (Singh, House, \& Tucker, 1986). The third variable we controlled for was capital structure, coded as 1 if a firm issued stock to raise capital and as 0 otherwise (Haveman, 1993).

\section{Analysis}

Hypotheses 1 and 2 were tested separately on both the CEO and the editor subgroups using lifetime data models with right-censored observations (Lawless, 1982: 31). This procedure allowed us to test the relational contract hypothesis (Hypothesis 3 ), which argues that the relation between an editor and a principal will tend to be confined to the exchange value of the transaction so that the editor's tenure will be more closely tied to observed performance and business risk outcomes than the tenure of the same newspaper's CEO.

For both the CEO and the editor, we measured the effects of family ties on the relationships between performance and tenure (Hypothesis 1) and business risk and tenure (Hypothesis 2) by calculating two models: one for executives with family ties and one for executives without family ties. For Hypothesis 1, the independent variables in both cases consisted of the two performance measures. For Hypothesis 2, the independent variables in both cases consisted of the business risk measure. Hypothesis 1 would be supported if the perfor- 
mance effect on tenure was greater for CEOs and editors without family ties than for their counterparts with such ties. Likewise, Hypothesis 2 would be supported if business risk were a stronger predictor of tenure for CEOs and editors who worked in a nonfamily rather than a family contracting situation.

A likelihood ratio statistic was used to ascertain if the corresponding coefficients were greater for one group than for the other (family versus nonfamily, CEOs versus editors), as predicted by $\mathrm{Hy}-$ potheses 1-3. A likelihood ratio statistic was also used to determine if the differences in the corresponding regression coefficients for the various subgroups were statistically significant and in the direction predicted by Hypotheses 1-3.

Hypothesis 4 was tested by calculating a survival model, whereby each CEO succession event was entered as an independent variable, and the length of a newspaper's survival up to the next succession event (if any) was used as a dependent variable. Each transition was coded as family if the new CEO was part of the extended family that owned the newspaper or as nonfamily if the new CEO had no family ties to the owners. Hypothesis 4 would be supported if the coefficients for CEO family transitions were positive, statistically significant, and greater than those for nonfamily CEO transitions.

\section{RESULTS}

Table 1 shows the correlation matrix for both CEOs and editors. As can be seen in that table, the correlation among the two performance measures (Hypothesis 1) and business risk (Hypothesis 2) is not very high, indicating that from a measurement perspective there is little redundancy between the first two hypotheses. Table 2 shows the results of analyses with CEO tenure as the dependent variable, broken down by those with (first three columns) and without (last three columns) family ties to owners. Table 3 is equivalent to Table 2, except that the results pertain to editor tenure.

As can be seen in columns 4 and 5 of Table 2 (CEOs) and Table 3 (editors), in three out of the four entries firm performance predicts the tenure of nonfamily executives. In contrast, columns 1 and 2 of these tables (results for those with family ties) show that for neither CEOs (Table 2) nor editors (Table 3) is there any relationship between performance and executive tenure. With the exception of one performance measure (column 4 of Table 2), the differences shown in Tables 2 and 3 between the corresponding coefficients for family and nonfamily status are statistically significant at $p \leq$ .0001 using the likelihood ratio statistics test, strongly supporting Hypothesis 1. In other words, under family contracting, dismissal of agents is a less likely response to negative performance results.

Tables 2 (CEO) and 3 (editor) also show the impact of business risk on the tenure of these two executives as a function of family status. Comparing columns 3 and 6 in Table 2 , we see that a newspaper's business risk exerts a much stronger negative influence on the tenure of nonfamily CEOs ( $p \leq .01)$ than on the tenure of family CEOs (n.s.). These differences are statistically significant ( $p \leq$ .001 , likelihood ratio test). The corresponding columns in Table 3 show the same effect for editors, with business risk exerting a very high impact on the tenure of nonfamily editors $(p \leq .0001)$ and no statistically significant impact on editors with family ties to their CEOs. These differences are statis-

TABLE 1

Means, Standard Deviations, and Correlations ${ }^{a}$

\begin{tabular}{|c|c|c|c|c|c|c|c|c|c|c|c|}
\hline \multirow[b]{2}{*}{ Variable } & \multicolumn{2}{|c|}{ CEO } & \multicolumn{2}{|c|}{ Editor } & \multirow[b]{2}{*}{$\mathbf{1}$} & \multirow[b]{2}{*}{2} & \multirow[b]{2}{*}{3} & \multirow[b]{2}{*}{4} & \multirow[b]{2}{*}{5} & \multirow[b]{2}{*}{6} & \multirow[b]{2}{*}{7} \\
\hline & Mean & s.d. & Mean & s.d. & & & & & & & \\
\hline 1. Density & 129.75 & 11.84 & 129.00 & 11.29 & & $.99 * \star \star \star$ & -.01 & $.22^{\star \star \star \star *}$ & $.22^{\star \star \star \star}$ & .03 & $.17^{\star * \star}$ \\
\hline 2. Density squared/100 & 169.75 & 30.87 & 167.69 & 29.51 & $.99^{* \star * *}$ & & -.01 & $.23^{* * * *}$ & $.23 * * * *$ & .03 & $.17 * * *$ \\
\hline 3. Capital structure & 0.96 & 0.18 & 0.95 & 0.20 & -.08 & -.08 & & .03 & .00 & .03 & -.00 \\
\hline 4. Performance trend & 0.07 & 0.40 & 0.06 & 0.32 & $.12 *$ & $.12^{*}$ & .02 & & $.59 * * * *$ & .07 & $.22 * * * *$ \\
\hline 5. Performance changes & 0.03 & 0.32 & 0.01 & 0.26 & $.14^{\star}$ & $.14^{\star}$ & .02 & $.65^{\star * \star *}$ & & -.02 & .14 \\
\hline 6. Business risk & -1.04 & 0.89 & -1.02 & 0.86 & .06 & .07 & .06 & .03 & .04 & & $-.19^{* * * *}$ \\
\hline 7. Tenure & 5.61 & 5.37 & 4.57 & 4.94 & -.03 & -.02 & -.05 & .06 & $.14^{*}$ & $.21 * * \star \star$ & \\
\hline
\end{tabular}

${ }^{\text {a }}$ Correlations above the diagonal correspond to the editor; correlations below the diagonal correspond to the CEO.

${ }^{*} p<.05$

$\star \star p<.01$

$\star * * p<.001$

$\star * \star * p<.0001$ 
TABLE 2

Effects of Performance and Business Risk on CEO Tenure ${ }^{a}$

\begin{tabular}{|c|c|c|c|c|c|c|}
\hline \multirow[b]{2}{*}{ Variable } & \multicolumn{3}{|c|}{ Family Ties } & \multicolumn{3}{|c|}{ No Family Ties } \\
\hline & $\begin{array}{l}\text { Performance } \\
\text { Trend }\end{array}$ & $\begin{array}{l}\text { Performance } \\
\text { Changes }\end{array}$ & $\begin{array}{l}\text { Business } \\
\text { Risk }\end{array}$ & $\begin{array}{l}\text { Performance } \\
\text { Trend }\end{array}$ & $\begin{array}{c}\text { Performance } \\
\text { Changes }\end{array}$ & $\begin{array}{c}\text { Business } \\
\text { Risk }\end{array}$ \\
\hline Density & $-0.79^{*}(0.39)$ & $-1.09 * *(0.40)$ & $-0.77^{*}(0.38)$ & $-0.04(0.43)$ & $-0.06(0.42)$ & $-0.35(0.39)$ \\
\hline Density squared/100 & $0.31 *(0.15)$ & $0.43^{* *}(0.15\}$ & $0.30^{*}(0.15)$ & $0.02(0.17)$ & $0.88(0.16)$ & $0.15(0.15)$ \\
\hline Capital structure & $-0.68(0.78)$ & $-0.60(0.94)$ & $-0.58(0.77)$ & & & \\
\hline Business risk & & & $-0.13(0.15)$ & & & $-0.56^{* *}(0.17)$ \\
\hline Constant & $52.75^{\star}(25.06)$ & $70.74^{\star \star}(25.66)$ & $51.03^{*}(24.88)$ & $3.00(27.75)$ & $2.50(26.98)$ & $22.11(24.97)$ \\
\hline$\chi^{2}$ & $8.43^{+}$ & 6.60 & $9.13^{+}$ & 3.58 & $15.69^{\star *}$ & $12.61^{* *}$ \\
\hline$d f$ & 4 & 4 & 4 & 3 & 3 & 3 \\
\hline
\end{tabular}

${ }^{a}$ For the group with family ties, $n=227$. For the group without family ties, $n=86$. Values are unstandardized regression coefficients; values in parentheses are standard errors.

$$
\begin{aligned}
{ }^{*} p & <.10 \\
{ }^{*} p & <.05 \\
{ }^{*} p & <.01
\end{aligned}
$$

\begin{tabular}{|c|c|c|c|c|c|c|}
\hline \multirow[b]{2}{*}{ Variable } & \multicolumn{3}{|c|}{ Family Ties } & \multicolumn{3}{|c|}{ No Family Ties } \\
\hline & $\begin{array}{c}\text { Performance } \\
\text { Trend }\end{array}$ & $\begin{array}{c}\text { Performance } \\
\text { Changes }\end{array}$ & $\begin{array}{c}\text { Business } \\
\text { Risk }\end{array}$ & $\begin{array}{c}\text { Performance } \\
\text { Trend }\end{array}$ & $\begin{array}{c}\text { Performance } \\
\text { Changes }\end{array}$ & $\begin{array}{c}\text { Business } \\
\text { Risk }\end{array}$ \\
\hline Density & $-0.29(0.65)$ & $0.35(0.51)$ & $-0.17(0.62)$ & $-0.31(0.20)$ & $-0.49^{\star}(0.19)$ & $-0.34^{+}(0.20)$ \\
\hline Density squared/100 & $0.14(0.25)$ & $-0.11(0.20)$ & $0.10(0.24)$ & $0.13^{+}(0.08)$ & $0.20^{\star \star}(0.07)$ & $0.14^{+}(0.08)$ \\
\hline Capital structure & $0.61(0.54)$ & $0.21(0.47)$ & $0.40(0.53)$ & $0.18(0.48)$ & $0.45(0.45)$ & $0.42(0.47)$ \\
\hline Performance trend & $0.76(0.78)$ & & & $0.93^{* * *}(0.26)$ & & \\
\hline Performance changes & & $0.73(0.57)$ & & & $0.71^{\star}(0.32)$ & \\
\hline Business risk & & & $-0.56^{+}(0.29)$ & & & $-0.39^{* \star * *}(0.09)$ \\
\hline Constant & $14.86(42.42)$ & $-25.52(33.30)$ & $7.08(40.43)$ & $19.30(13.19)$ & $29.92^{\star}(12.33)$ & $20.53(12.86)$ \\
\hline$\chi^{2}$ & $14.00^{* *}$ & 12.77 & $16.58^{* *}$ & $75.24^{\star * * *}$ & $41.08^{\star * * *}$ & $41.00 * * * *$ \\
\hline$d f$ & 4 & 4 & 4 & 4 & 4 & 4 \\
\hline
\end{tabular}

TABLE 3

Effects of Performance and Business Risk on Editor Tenure ${ }^{a}$

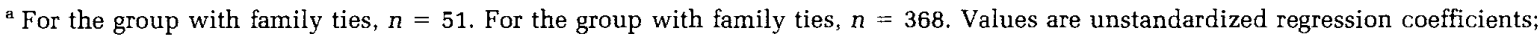
values in parentheses are standard errors.

$$
\begin{aligned}
{ }^{*} p & <.10 \\
{ }^{*} p & <.05 \\
{ }^{* *} p & <.01 \\
{ }^{* * *} p & <.001 \\
* * * * & <.0001
\end{aligned}
$$

tically significant at $p \leq .0001$. Consistent with Hypothesis 2, this finding indicates that executives who do not benefit from a family contract face greater employment risk from business risk than their family counterparts. Another way of looking at this is that there is greater risk sharing between firm and agent when the executive is not buffered by a family contract.

Although Hypotheses 1 and 2 generally hold true for both CEOs and editors, a close examination of Tables 2 (CEO) and 3 (editor) indicate that there is some evidence for the existence of a stronger relational contract for CEOs than for editors. For editors without family ties to CEOs, both performance measures are linked to tenure, one at $p \leq .001$ (column 4, Table 3) and one at $p \leq .05$ (column 5, Table 3). In the case of CEOs, only one of the two performance measures reaches statistical significance at $p \leq .05$ (column 5, Table 2). The differences between the coefficients in columns 4 of Tables 2 and 3 are statistically significant at $p \leq$ .0001 . Results also show that for nonfamily execu- 
tives, the sensitivity of tenure to business risk tends to be greater for editors ( $p \leq .0001$, Table 3 ) than for CEOs $(p \leq .01$, Table 4$)$. The differences between the coefficients in columns 6 of Tables 2 (CEO) and 3 (editor) are marginally significant at $p \leq .10$.

To summarize the findings reported so far, it is evident that the overwhelming factor that determines the sensitivity of executive tenure to performance and business risk is family status. However, for agents without family ties to principals, results suggest that those with more strongly relational contracts (that is, CEOs) are evaluated less closely on the basis of observed outcome measures.

The corresponding results for Hypothesis 4 are summarized in Table 4, which indicates that the consequences for firm survival of change from a CEO with family ties to owners are positive and statistically significant. In the case of nonfamily CEOs, executive successions have no effect on firm survival. These results support Hypothesis 4. In other words, if a CEO stays on the job longer than can be justified on the basis of observed results (as per Hypotheses 1 and 2), the positive consequences of replacing a family member are greater than the positive consequences of replacing a CEO who is not a family member.

\section{DISCUSSION AND CONCLUSIONS}

The results presented here indicate that monitoring mechanisms operate differently under family and nonfamily principal-agent contracts and under stronger and weaker relational contracts. This pat-

TABLE 4

Effects of CEO Succession on Length of Organizational Survival ${ }^{a}$

\begin{tabular}{|c|c|}
\hline Variable & Length of Survival \\
\hline Density & $-2.17^{\star \star \star \star}(0.38)$ \\
\hline Density squared/100 & $0.89^{\star \star * *}(0.15)$ \\
\hline Capital structure & $0.48(0.43)$ \\
\hline First succession, nonfamily & $-0.24(0.49)$ \\
\hline Second succession, nonfamily & $-0.10(0.65)$ \\
\hline Third succession, nonfamily & $0.75(1.09)$ \\
\hline Fourth succession, nonfamily & $4.58(38.45)$ \\
\hline First succession, family & $0.86^{\star}(0.41)$ \\
\hline Second succession, family & $1.07^{* *}(0.35)$ \\
\hline Constant & $132.65^{\star \star \star \star}(23.46)$ \\
\hline$\chi^{2}$ & $123.33^{\star \star \star \star}$ \\
\hline$\hat{d f}$ & 9 \\
\hline \multicolumn{2}{|c|}{$\begin{array}{l}{ }^{a} \text { Values are unstandardized regression coefficients; values in } \\
\text { parentheses are standard errors. } \\
\qquad \begin{array}{l}{ }^{\star} p<.05 \\
{ }^{\star *} p<.01 \\
{ }^{\star \star \star *} p<.0001\end{array}\end{array}$} \\
\hline
\end{tabular}

tern is evidenced by the fact that the links between performance, business risk, and executive tenure are stronger when agents have no family ties to principals and are also stronger for newspaper editors than for CEOs.

The study also indicates that the organizational consequences of CEO dismissal are stronger when a replaced CEO is a family member. Results showed that organizational survival length increased when family CEOs were replaced but did not when there was a change in command among their nonfamily counterparts. In conjunction with the results confirming Hypotheses 1 and 2, this finding suggests that family CEOs are not necessarily driven by a common family interest and that steps taken to increase their accountability reduce agency costs (as evidenced by longer firm survival). Thus, although the benefits of achieving "good agency" cannot be directly measured, we can deduce from these findings that when appropriate monitoring mechanisms are in place, agency threats in family firms are less severe.

\section{Overview of Results}

This study empirically supports what some of the anecdotal evidence in the family business literature indicates. For example, Prokesch (1991) referred to the case of the Marriott Corporation, one of the best-managed hotel and food services companies in the world. Willard Marriott, Jr., chairman of the board and son of the corporation's founders, boasts that Marriott's endurance and success as a closely held family firm can be attributed in large measure to the "easing out of unproductive relatives" (that is, achieving lower agency costs through effective monitoring). The practical implications of this view are enormous, given the low life expectancy and poor survival rates of familyowned businesses. For instance, Ward (cited in Prokesch, 1991: 180) reported that only 6 out of 200 firms in his study survived more than 60 years. Similarly, Benson (1991) noted that less than 13 percent of family businesses survive to the next generation. Obviously, the problem of agency is only one of many factors contributing to these grim statistics; however, consistent with our data, it is likely that "a major reason [for the high failure rate] is the conflicting needs of business and family" (Benson, 1991: 327).

We have interpreted the fact that tenure is less sensitive to firm performance and business risk indicators for CEOs than for editors as evidence that the former operate under more strongly relational (longer-term) contracts than the latter. An alternative interpretation is that the presence of a 
more strongly relational contract for the CEO position facilitates the incumbent's entrenchment, to the detriment of the principal. In other words, an executive under a strongly relational contract (that is, a CEO) may take advantage of a principal by decoupling employment risk (being replaced) from observed performance outcomes. In turn, an executive under a more weakly relational contract (that is, an editor) may be blamed for poor performance and serve as a scapegoat for disappointing results. We have no way to directly test this alternative "power interpretation" (e.g., Allen \& Panian, 1982), but we do not view it as a very plausible one in the context of this study. This is because the observed differences between the CEOs and editors for the coefficients of interest (the two performance variables and the business risk measure) occurred only when there were no family ties. And, given that all the firms studied were closely held, both theory and empirical research would suggest that their owners should have had a strong interest in closely monitoring executive behaviors (Tosi et al., 1999). It is therefore unlikely that in our sample, nonfamily CEOs would be allowed to receive more favorable treatment or to get away with more self-serving behaviors than editors. In other words, high ownership concentration in the hands of family members would make it difficult for nonfamily CEOs to garner enough power to deflect scapegoating and pass blame on to their fellow executives (their editors).

The research reported here does not support the notion that managerial succession is merely a symbolic event that has no effect on firm survival (Brown, 1982; Gamson \& Scotch, 1964) or the view that it tends to precipitate organizational failure, as argued by population ecologists (e.g., Carroll, 1984; Freeman, Carroll, \& Haveman, 1983; Haveman, 1993). We found exactly the opposite in the case of CEOs who were family members, a pattern more in line with the argument that disciplining managers (through dismissal) when monitoring is low (under a family contract) enhances organizational survival. This view is consistent with earlier research by Tosi and Gomez-Mejia (1994) showing that marginal returns to monitoring are a decreasing function of the level of monitoring. In that study, the authors found that increased CEO monitoring was associated with improved firm performance when monitoring was low but not when monitoring was high.

\section{An Agenda for Future Research}

There are several interesting empirical issues that could not be examined in this study because the data were not available. Three of these are particularly salient. The first one is ownership structure. We had no information on how firm stock was distributed among the relevant parties. This distribution is important because it is likely to influence the power structure within a firm and the potential for agency problems. For example, using a sample of large American firms, Morck, Shleifer, and Vishny (1988) found that the relationship between agency costs and CEO stock ownership was curvilinear. At very low levels of stock ownership (which they defined as 5 percent or less), a CEO had no leverage and thus very little power; at high levels of stock ownership (25 percent or more), however, the principal and agent were almost isomorphic. In both cases, agency problems were not significant. According to Morck and his colleagues, agency problems are most severe in the midrange of the CEO ownership distribution $(6-24 \%)$ because in this range the CEO enjoys sufficient power to act in a self-serving manner, at the expense of other shareholders, and do so with relative impunity. Although the operational definitions of low, middle, and high CEO stock ownership should probably be different in smaller, closely held family firms, the logic of Morck and his coauthors is compelling and provides a fertile arena for future theorizing and empirical work on family business.

A second issue is board composition. A large literature, almost all of it United States-based, focuses on the characteristics of board of directors and the influence these have on the monitoring and incentive alignment of CEOs. Studied characteristics include the proportions of insiders and outsiders on a board, whether or not CEOs are allowed to serve as board chairs, and board interlocks (for reviews of this literature, see Kosnik and Chatterjee [1997] and Finkelstein and Hambrick [1996]). Results of these studies have generally been mixed, but this literature suggests a number of boardrelated factors that could be examined in light of the hypotheses posited here. Research might, for example, address board size, board stock ownership, the proportion of family members on a board, and the presence of a firm's CEO and founder on the board. These data should be available in archival U.S. sources for both family-owned and nonfamily-owned firms as long as they are publicly traded.

Lastly, executive pay instead of tenure could be examined as a dependent variable to test Hypotheses 1-3. Extending the arguments presented here, we would expect that the sensitivity of CEO compensation (typically measured in terms of pay level, pay changes, and pay mix) to performance and business risk would vary according to CEO 
family ties to owners and the strength of relational contracts. Just as in the case of the board characteristics discussed above, this information can be obtained from archival sources for all family and nonfamily publicly traded U.S. firms. Unfortunately, these data are inaccessible or unavailable in almost all other countries (England being a notable exception).

\section{Limitations}

As noted earlier, the population of newspapers used here has the distinct advantage of controlling for many extraneous factors that may affect the results. On the downside, there is a possibility that the results are not generalizable to other settings. For example, perhaps the salutary or negative effects of executive succession are peculiar to each organizational population. Its impact may be more disruptive in other populations, such as those used by Haveman (1993), Carroll (1984), and Amburgey, Kelly, and Barnett (1993). It is also possible that national culture exerts some influence on the findings reported here. In Spain, as in most Latin countries, close-knit families are the norm, and there is strong expectation of individual loyalty to the extended family and vice versa. One could speculate that in highly individualistic countries, like the United States, where norms of family reciprocity and interdependence are weaker, the differences between family and nonfamily contracting would not be as sharp as those we observed in Spain. This is another interesting question that could be addressed in a comparative international research.

\section{Conclusions}

This study represents a first step toward better understanding agency issues in family-owned firms and the effect of the nature of the studied executive position on the strength of the relational contract. Although much research remains to be done, this study suggests that principal-agent family bonds may increase agency costs but that these costs can be curtailed by use of appropriate monitoring mechanisms within the family business. Although results were not as compelling for nonfamily contracting, our study suggests that even these relational contracts tend to attenuate the link between tenure and observed performance.

\section{REFERENCES}

Allen, M. P., \& Panian, S. K. 1982. Power, performance and succession in the large corporation. Administrative Science Quarterly, 27: 538-547.
Amburgey, T., Kelly, D., \& Barnett, W. 1993. Resetting the clock: The dynamics of organizational change and failure. Administrative Science Quarterly, 38: 51-73.

Applegate, J. 1994. Keep your firm in the family. Money, 23: $88-91$.

Baysinger, B. D., Kosnik, R. D., \& Turk, T. A. 1991. Effects of board and ownership structure on corporate R\&D strategy. Academy of Management Journal, 34: 205-214.

Benson, B. 1991. Greating a board of directors: When success demands too much. In C. E. Aronoff \& J. L. Ward (Eds.), Family business sourcebook: 325-333. Detroit: Omnigraphics.

Bigley, G. A., \& Pearce. 1998. Straining for shared meaning in organization science: Problems of trust and distrust. Academy of Management Review, 23: $405-421$.

Brown, M. 1982. Administrative succession and organizational performance: The succession effect. Administrative Science Quarterly, 27: 1-16.

Carroll, G. 1984. Dynamics of publisher succession in newspaper organizations. Administrative Science Quarterly, 29: 303-329.

Chatterjee, S., Lubatkin, M. H., \& Shulze, W. S. 1999. Toward a strategic theory of risk premium: Moving beyond CAPM. Academy of Management Review, 24: 556-568.

Coffee, J. 1988. Shareholder versus managers: The strain in the corporate web. In J. C. Coffee, L. Lowenstein, \& S. Rose-Ackerman (Eds.), Knights, raiders and targets! 77-134. New York: Oxford University Press.

Cox, D. R., \& Oakes, D. 1984. Analysis of survival data. London: Chapman and Hall.

Crane, M. 1985. How to keep families from feuding. In P. C. Rosenblatt, L. deMik, R. M. Anderson, \& P. A. Johnson (Eds.), The family in business: $458-463$. San Francisco: Jossey-Bass.

Das, T. K., \& Teng, B. S. 1998. Time and entrepreneurial risk behavior. Entrepreneurship Theory and Practice, 22: $69-82$.

Davis, P. S., \& Harveston, P. D. 1998. The influence of the family on the family business succession process: A multi-generational perspective. Entrepreneurship Theory and Practice, 22: 31-53.

Donnelly, R. G. 1964. The family business. Harvard Business Review, 42(4): 93-105.

Dyer, W. G. 1988. Integrating professional management into a family owned business. Family Business Review, 1(3): 221-235.

Dyer, W. G. 1994. Potential contributions of organizational behavior to the study of family owned businesses. Family Business Review, 7(2): 109-134.

Fahquar, K. A. 1989. Employee responses to external executive succession: Attributions and the emer- 
gence of leadership. Unpublished doctoral dissertation, Boston University.

Finkelstein, S., \& Hambrick, D. C. 1990. Top management team tenure and organizational outcomes: The moderating role of managerial discretion. Administrative Science Quarterly, 35: 484-503.

Finkelstein, S., \& Hambrick, D. 1996. Strategic.leadership: Top executives and their effects on organizations. St Paul: West.

Freeman, J., Carroll, G., \& Hannan, M. 1983. The liability of newness: Age dependence in death rates. American Sociological Review, 48: 692-710.

Gamson, W., \& Scotch, N. 1964. Scapegoating in baseball. American Journal of Sociology, 70: 69-72.

Gomez-Mejia, L. R., \& Wiseman, R. 1997. Reframing executive compensation. Journal of Management, 23: 291-374.

Hambrick, D. C., Black, S., \& Fredrickson, J. W. 1992. Executive leadership of the high technology firm: What is special about it. In L. R. Gomez-Mejia \& M. W. Lawless (Eds.), Top management and executive leadership in high technology: 3-19. Greenwich, CT: JAI Press.

Hambrick, D. C., \& Fukutomi, G. D. S. 1991. The seasons of a CEO tenure. Academy of Management Review, 16: $719-742$.

Handler, W. C., \& Kram, K. E. 1988. Succession in family firms: The problem of resistance. Family Business Review, 1: 361-381.

Harris, M., \& Raviv, A. 1978. Some results on incentive contracts with applications to education, health insurance, and law enforcement. American Economic Review, 68(March): 20-30.

Haveman, H. A. 1993. Ghosts of managers past: Managerial succession and organizational mortality. Academy of Management Journal, 36: 864-881.

Hollander, B. S. 1983. Family owned business as a system. Unpublished doctoral dissertation, University of Pittsburgh.

Holmes, J. G. 1991. Trust and the appraisal process in close relationships. In W. H. Jones \& D. Perlman (Eds.), Advances in personal relationships, vol. 2: 57-104. London: Jessica Kingsley.

Hoskisson, R. E., Hitt, M. A., \& Hill, C. W. L. 1993. Managerial incentives and investment in $R \& D$ in large multiproduct firms. Organization Science, 4: $325-341$.

James, D. R., \& Sorel, M. 1981. Profit constraints on managerial autonomy: Managerial theory and the unmaking of the corporation president. American Sociological Review, 46: 1-18.

Jensen, M. C., \& Meckling, W. H. 1976. Theory of the firm: Managerial behavior, agency costs, and ownership structure. Journal of Financial Economy, 3: 305-350.
Jones, G. R. 1983. Transaction costs, property rights, and organizational culture: An exchange perspective. Administrative Science Quarterly, 28: 454-467.

Kanter, R. M. 1989. Work and family in the United States: A critical review and agenda for research and policy. Family Business Review, 2: 77-114.

Katz, R. 1982. The effects of group longevity on project communication and performance. Administrative Science Quarterly, 27: 81-104.

Kay, N. M. 1992. Markets, false hierarchies, and the evolution of modern corporations. Journal of Economic Behavior and Organization, 17: 315-333.

Kaye, A. 1991. Penetrating the cycle of sustained conflict. Family Business Review, 4: 22-44.

Kosnik, R. D., \& Chatterjee, S. 1997. Corporate governance. St. Paul: West.

Lambert, R. A. 1983. Long-term contracts and moral hazard. Bell Journal of Economics, 14: 441-445.

Lawless, J. F. 1982. Statistical models and methods for lifetime data. New York: Wiley.

Levinson, H. 1983. Consulting with family businesses: What to look for what to look out for. Organizational Dynamics, 14(1): 71-80.

Liebowitz, B. 1986. Resolving conflict in the family owned business. Consultation, 5: 603-615.

Litz, R. A. 1997. Explaining the void; addressing the opportunity. Entrepreneurship Theory and Practice, 21: 55-70.

Madura, J., Martin, A. D., \& Jessell, K. A. 1996. Determinants of CEO compensation in small traded businesses. American Business Review, 14: 80-89.

McAllister, D. J. 1995. Affect- and cognition-based trust as foundations for interpersonal cooperation in organizations. Academy of Management Journal, 38: 24-59.

McEachern, W. 1975. Managerial control and performance. Lexington, MA: Heath.

Milgrom, P., \& Roberts, J. 1992. Economics, organization, and management. Englewood Cliffs, NJ: Prentice-Hall.

Miller, E. J., \& Rice, A. A. 1967. Systems of organizations. London: Tavistock.

Miller, K. D., \& Reuer, J. 1996. Measuring organizational downside risk. Strategic Management Journal, 17: 671-691.

Morck, R., Shleifer, A., \& Vishny, R. W. 1988. Management ownership and market valuation: An empirical analysis. Journal of Financial Economics, 20: 293315.

Neubauer, F., \& Lank, A. G. 1998. The family business. Its governance and sustainability. London: Macmillan.

Peiser, R. B., \& Wooten, L. M. 1991. Life-cycle changes in small family businesses. In C. E. Aronoff \& J. L. Ward 
(Eds.), Family business sourcebook: 430-441. Detroit: Omnigraphics.

Portales, C., Ricart, J. E., \& Rosanas, J. M. 1998. Understanding trust to build strong relationships in organizations. In M. A. Hitt, J. E. Costa, \& R. D. Nixon (Eds.), Interconnected perspectives: Strategies, competence, and performance. Chichester, England: Wiley.

Prokesch, S. 1991. Rediscovering family values. In C. E. Aronoff \& J. L. Ward (Eds.), Family business sourcebook: 126-144. Detroit: Omnigraphics.

Ross, S. 1973. The economic theory of agency: The principal's problem. American Economic Review, 63(March): 134-139.

Rousseau, D. M., Sitkin, S. B., Burt, R. S., \& Camerer, C. 1998. Not so different after all: A cross-discipline view of trust. Academy of Management Review, 23: 393-405.

Ruefli, T. W., Collins, J. M., \& Lacugna, J. R. 1999. Risk measures in strategic management. Strategic Management Journal, 20: 167-194.

Schulze, W. S., Dino, R. W., Lubatkin, M., \& Buchholtz, A. K. 1999. Agency relationships in family firms: Theory and evidence. Unpublished manuscript, Management Department, University of Connecticut.

Shapira, S. 1995. Risk taking: A managerial perspective. New York: Sage.

Shavell, S. 1979. Risk sharing and incentives in the principal and agent relationship. Bell Journal of Economics, 10: 55-73.

Singh, J., House, R., \& Tucker, D. 1986. Organizational change and organizational mortality. Administrative Science Quarterly, 31: 587-611.

Smith, A. 1980. Goodbye Gutenberg. The newspaper revolution of the 1980's. New York: Oxford University Press.

Sohn, A., Ogan, C., \& Polich, J. 1986. Newspaper leadership. Englewood Cliffs, N.J.: Prentice-Hall.

Tosi, H. L., \& Gomez-Mejia, L. R. 1994. Compensation monitoring and firm performance. Academy of Management Journal, 37: 1002-1016.
Tosi, H. L., Gomez-Mejia, L. R., Loughry, M. L., Werner, S., Banning, K., Katz, J., Harris, R., \& Silva, D. 1999. Managerial discretion, compensation strategy, and firm performance: The case for ownership structure. In G. Ferris (Ed.), Research in personnel and human resources management, vol. 17: 163-209. Stamford, CT: JAI Press.

Tosi, H. L., Katz, J., \& Gomez-Mejia, L. R. 1997. Disaggregating the agency contract: The effects of monitoring, incentive alignment, and CEO tenure on managerial decision making. Academy of Management Journal, 40: 584-602.

Walsh, J. P., \& Seward, J. K. 1990. On the efficiency of internal and external corporate control mechanisms. Academy of Management Review, 15: 421-458.

Wiseman, R. M., \& Gomez-Mejia, L. R. 1998. A behavioral agency model of managerial risk taking. Academy of Management Review, 25: 133-152.

Zaheer, A., \& Venkatraman, N. 1995. Relational governance as a interorganizational strategy: An empirical test of the role of trust in economic exchange. Strategic Management Journal, 16: 373-392.

Luis R. Gomez-Mejia is the Dean's Council of 100 Distinguished Scholar and a professor at Arizona State University's College of Business. He received his Ph.D. from the University of Minnesota. His research interests are macro compensation issues, including executive compensation and compensation strategy.

Manuel Nuñez-Nickel is an assistant professor of accounting at Carlos III University. He received his Ph.D. from Carlos III University. His current research interests are liquidity analysis, the quality of financial information in bankrupted firms, and corporate dissolution.

Isabel Gutierrez is a professor of management at Carlos III University. She received her Ph.D. from the University of Seville. Her current research interests include macro organizational issues, industry structure, and the dynamics of competitive interactions. She is also interested in the founding characteristics, strategy, and performance of entrepreneurial ventures. 